\title{
2016 Gordon Research Conference on Electron Donor Acceptor Interactions (GRC - EDAI)
}

\author{
Special Editor \\ Natia Frank \\ University of Victoria \\ Victoria, British Columbia
}

